\title{
30 years of upper air soundings on board of R/V POLARSTERN
}

\author{
Amelie Driemel, Bernd Loose, Hannes Grobe, Rainer Sieger, and Gert König-Langlo \\ Alfred-Wegener-Institut Helmholtz-Zentrum für Polar- und Meeresforschung, Bremerhaven, Germany \\ Correspondence to: Gert König-Langlo (gert.koenig-langlo@awi.de)
}

Received: 6 November 2015 - Published in Earth Syst. Sci. Data Discuss.: 11 March 2016

Revised: 20 May 2016 - Accepted: 21 May 2016 - Published: 1 June 2016

\begin{abstract}
The research vessel and supply icebreaker POLARSTERN is the flagship of the Alfred-WegenerInstitut in Bremerhaven (Germany) and one of the infrastructural pillars of German Antarctic research. Since its commissioning in 1982, POLARSTERN has conducted 30 campaigns to Antarctica (157 legs, mostly austral summer), and 29 to the Arctic (94 legs, northern summer). Usually, POLARSTERN is more than 300 days per year in operation and crosses the Atlantic Ocean in a meridional section twice a year. The first radiosonde on POLARSTERN was released on the 29 December 1982, 2 days after POLARSTERN started on its maiden voyage to the Antarctic. And these daily soundings have continued up to the present. Due to the fact that POLARSTERN has reliably and regularly been providing upper air observations from data sparse regions (oceans and polar regions), the radiosonde data are of special value for researchers and weather forecast services alike. In the course of 30 years (29 December 1982 to 25 November 2012) a total of 12378 radiosonde balloons were started on POLARSTERN. All radiosonde data can now be found at König-Langlo (2015, doi:10.1594/PANGAEA.810000). Each data set contains the directly measured parameters air temperature, relative humidity and air pressure, and the derived altitude, wind direction and wind speed. 432 data sets additionally contain ozone measurements.

Although more sophisticated techniques (meteorological satellites, aircraft observation, remote-sensing systems, etc.) have nowadays become increasingly important, the high vertical resolution and quality of radiosonde data remains paramount for weather forecasts and modelling approaches.
\end{abstract}

\section{Introduction}

For more than 30 years now, the research vessel and supply icebreaker POLARSTERN has been the flagship of the Alfred-Wegener-Institut in Bremerhaven (Germany). The commissioning of POLARSTERN on the 9 December 1982, was the result of a political decision to strengthen Germany's role in polar (at that time especially Antarctic) research: in 1978 the Federal Republic of Germany, represented by the Deutsche Forschungsgemeinschaft (DFG), became a member of the Scientific Committee on Antarctic Research (SCAR), and in 1980 the Alfred-Wegener-Institut für Polarforschung was founded (Fütterer and Fahrbach, 2007). $\mathrm{R} / \mathrm{V}$ POLARSTERN was thus bound to become one of the infrastructural pillars of German Antarctic research. Home port of POLARSTERN was and still is Bremerhaven, Germany. Since its commissioning, POLARSTERN has conducted 30 campaigns to Antarctica (157 legs, mostly austral summer), and 29 to the Arctic (94 legs, northern summer) ${ }^{1}$. Usually, POLARSTERN is more than 300 days per year in operation and crosses the Atlantic Ocean in a meridional section twice a year (Fütterer and Fahrbach, 2007). It is therefore the perfect basis for upper air observations in data-sparse regions (i.e. oceans and polar regions).

The first radiosonde on POLARSTERN was released on 29 December 1982, 2 days after POLARSTERN started on its maiden voyage to the Antarctic. Radiosondes are balloonborne instruments which record atmospheric ("upper air") profile data, mostly temperature, humidity and pressure. The horizontal wind vector can be estimated when the displacement of the balloon is known. As DuBois et al. (2002) wrote:

\footnotetext{
${ }^{1}$ The complete list of POLARSTERN campaigns can be found at https://www.pangaea.de/PHP/CruiseReports.php?b=Polarstern
} 
"The contributions of this relatively simple device to the late twentieth-century way of life can hardly be exaggerated. No other factor contributed more to the systematization of weather observations, which is beneficial to all who depend upon meteorological prediction. [...]". Radiosonde data are used extensively by weather forecast services, e.g. by the European Centre for Medium-Range Weather Forecasts (ECMWF). There are currently around 600-700 landand ship-based upper air observation stations routinely in operation worldwide which feed at least daily into the Global Telecommunication System (GTS) of the World Meteorological Organization. These data are used as input for routine weather forecast models such as the one run by the ECMWF. However, Fig. 1 shows that ocean and polar regions are underrepresented (see also Dow, 2004). Regular radiosonde launches on ships therefore are of special value, and icebreakers like POLARSTERN can even provide data from the Antarctic coast and the North Pole.

In the following, we describe a data compilation of 30 years of upper air soundings on board of POLARSTERN using VAISALA radiosondes. We first provide details on the equipment used, the sampling procedure, and the parameters measured. Then, the data compilation is described in respect to extent, access and quality. A few examples of the data types are also given. In the last part we give a short overview of related radiosonde data in PANGAEA, and finish with a look into the future.

\section{Instrumentation, sampling, parameters}

The upper air soundings on board of POLARSTERN were performed usually once a day at around 12:00 UTC. For this purpose the weather technician in charge released a heliumfilled balloon (TOTEX $600 \mathrm{~g}, 800 \mathrm{~g}$, Japan) equipped with a radiosonde (RS-type, VAISALA, Finland) from the helideck of POLARSTERN at a height of $10 \mathrm{~m}$ a.s.l. During strong wind conditions $\left(>20 \mathrm{~m} \mathrm{~s}^{-1}\right)$, only $350 \mathrm{~g}$ balloons could be launched with a reasonable chance of success. All balloons were filled to reach an ascent velocity of $5 \mathrm{~m} \mathrm{~s}^{-1}$; data recordings were made approximately every $25-50 \mathrm{~m}$ (until 6 June 1998 the profile data were taken every $10 \mathrm{~s}=$ around every $50 \mathrm{~m}$, later the sampling rate was increased to $5 \mathrm{~s}$ ). The bursting point of the balloon, which set an end to the recordings, mostly was between 25 and $37 \mathrm{~km}$ height (KönigLanglo et al., 2006). Up to 1996, RS80-15N sondes were used with the Omega wind finding technique. From 1996 on, when GPS came into use, we introduced the RS80-15G (with the change to $15 \mathrm{G}$ being a little bumpy resulting in the use of both types in 1996). Both sondes were equipped with RS80A-Humicap radiosonde humidity sensor. In October 2004 the RS80 sondes were replaced by RS90-AG radiosondes. Since 9 April 2005 RS92-SGPW radiosondes have been deployed, see Table 1 and König-Langlo (2015, doi:10.1594/PANGAEA.810000) for details.
Table 1. Overview of the radiosonde types on board $P O$ LARSTERN.

\begin{tabular}{lll}
\hline $\begin{array}{l}\text { Sonde } \\
\text { type }\end{array}$ & $\begin{array}{l}\text { Deployment } \\
\text { date }\end{array}$ & Campaign \\
\hline RS80 & 29 December 1982 to 1 October 2004 & Until ARK-XX/3 \\
RS90 & $\begin{array}{l}\text { 15 October 2004 to 4 April 2005 } \\
\text { RS92 }\end{array}$ & ANT-XXII/1-3 \\
\hline
\end{tabular}

The radiosondes directly measured air pressure, air temperature and relative humidity. Until 1996, the wind vector was determined with the aid of the OMEGA navigation system, since then a GPS-based windfinding system has been used, leading to a remarkable improvement in the quality of the horizontal wind vector. Altitudinal information was calculated using the hydrostatic approximation.

The recorded data were transmitted from the sondes to POLARSTERN. Data reception and evaluation on POLARSTERN was carried out by a MicroCora (VAISALA, Finland) until 1996. After that the system was switched to a DigiCORA MW11, in 2003 to a DigiCORA MW21 and since 2012 a DigiCORA MW31 has been used (VAISALA, Finland).

During some cruises ozone profiles through the troposphere and the lower stratosphere were measured by connecting an ozonesonde (ECC-6A, ECC-6B, Science Pump Corporation, USA) to a normal radiosonde using an interface. Ozone concentration was measured by pumping air through a chemical solution and using the principal of iodide redox reaction to release electrons. $1500 \mathrm{~g}$ TOTEX balloons were used for these ascents. The DigiCORA was able to handle the data reception and evaluation of both the normal radiosonde and the ozonesonde, simultaneously.

Together with hourly synoptical observations on board of POLARSTERN, radiosonde data were fed near real-time into the GTS via the DWD (German weather service) and used routinely by various weather forecast services, such as the ECMWF. In the ECMWF "Monthly Monitoring Report" (available at http://www.ecmwf.int/en/forecasts/ quality-our-forecasts/monitoring-observing-system/ ecmwf-global-data-monitoring-report-archive), e.g., you can find POLARSTERN meteorological data under the "WMO Identifier" DBLK (which is the ship's call sign).

\section{Data sets, data access, examples, data quality, related data}

\subsection{Data sets and data access}

In total 12378 radiosonde balloons were started on POLARSTERN in the course of 30 years (from 29 December 1982 to 25 November 2012). All radiosonde data can now be found at König-Langlo (2015, doi:10.1594/PANGAEA.810000). The single radiosonde launches have been grouped into so-called "parents" accord- 


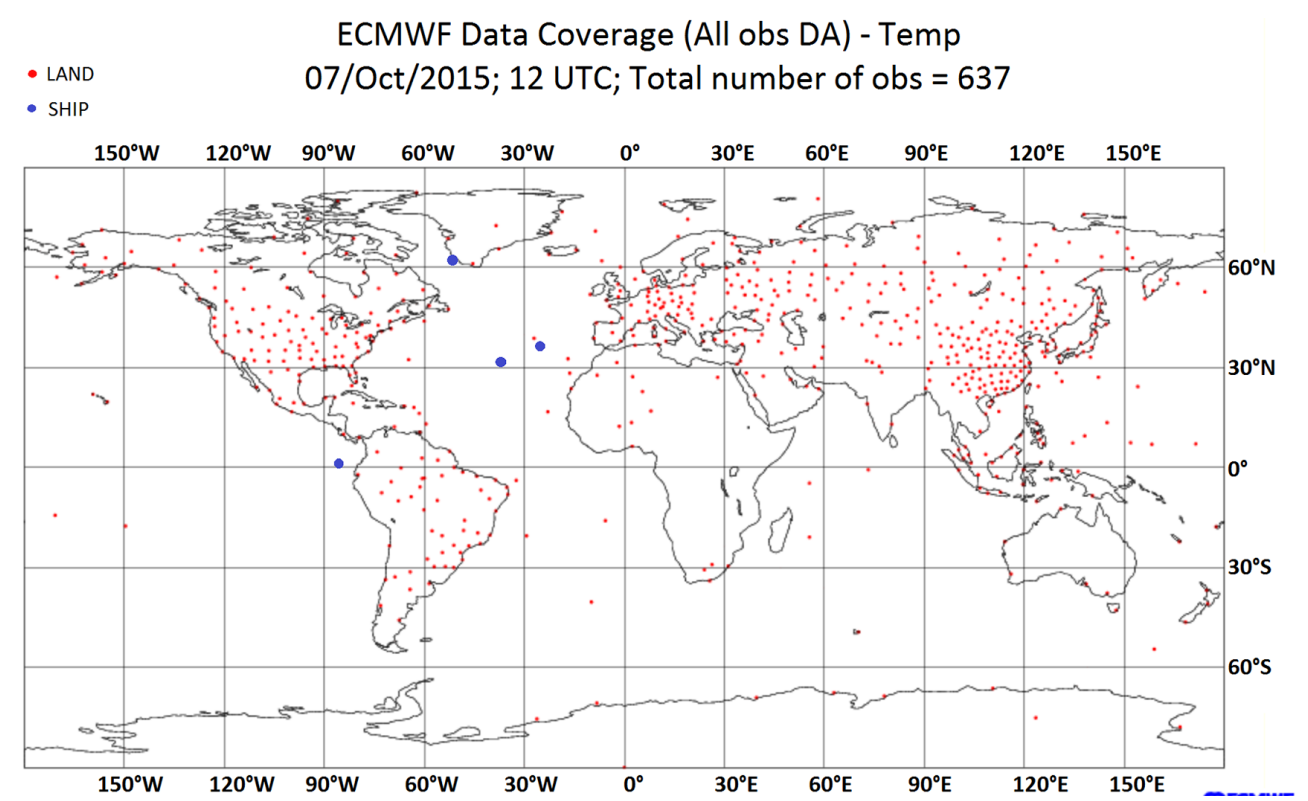

Figure 1. Example of data coverage of upper air soundings feeding into the ECMWF on 7 October 2015 at 12:00 UTC. Ship-based radiosonde launch sites (here $N=4$ ) have been enlarged to be able to distinguish them. Source: http://old.ecmwf.int/products/forecasts/d/ charts/monitoring/coverage.

ing to the cruise leg they belong to (i.e. a parent contains all data sets of one cruise leg, all in all 210 legs $=$ parents).

At König-Langlo (2015, doi:10.1594/PANGAEA.810000) you will find an overview table with information on the dates of the cruise leg, the number of single observations (i.e. launches), the sonde type used and links to the individual parents and respective cruise reports. Please note that cruise labels for Antarctic cruises always begin with "ANT", the ones for Arctic cruises with "ARK-". POLARSTERN radiosonde data for specific campaigns, areas or dates can also be searched by using the PANGAEA search engine (www.pangaea.de) and adding $+\mathrm{PSradio}^{2}$ for a search in all parents, or by adding + PSradiosingle ${ }^{3}$ for a search in all single radiosonde data sets ("childs"). Apart from the actual data (pressure, temperature, relative humidity, wind direction and wind speed according to altitude), each radiosonde data set contains the information of when and where it was launched. Whenever possible, the height of the tropopause, the precipitable water content and the total ozone are also given. Furthermore, the central parent offers the link to the cruise report of the respective cruise leg (if available).

In Fig. 2 all radiosonde launch sites of 30 years of $P O$ LARSTERN campaigns are mapped. The location of the homeport (Bremerhaven, North Sea) and the most frequent destinations of POLARSTERN (the Arctic and Neumayer Station, Weddell Sea) entail, that the radiosonde launch sites

\footnotetext{
${ }^{2}$ Try for example ozone + PSradio to obtain all parents (= cruise legs) containing data sets with ozone data

${ }^{3}$ Try for example ozone + PSradiosingle to obtain all radiosonde data sets containing ozone data
}

are mostly restricted to Atlantic Ocean regions. In terms of latitudinal coverage of the 12378 radiosonde launches Fig. 3 confirms that high latitudes are indeed very well represented in our data. For the interested user, Fig. 3 also shows the distribution of launches according to year.

\subsection{Data examples for interested users}

Of the 12378 single radiosonde launches, 432 contain ozone data. In Fig. 5 the ozone data of POLARSTERN cruise ANT-XVII (launch sites see Fig. 4) are plotted against altitude and latitude, irrespective of the longitude, date or time of measurement (tool used to create Figs. 4-7 is ODV by Schlitzer, 2015). Nevertheless, the distribution of stratospheric ozone, shaped by the Brewer-Dobson circulation, can be seen nicely.

Figure 6 shows an example of a meridional-height section of air temperature (again data from cruise ANT-XVII). Here, the low temperatures of the tropopause near the equator are apparent. With higher latitudes, the tropopause reaches lower altitudes and gets increasingly warmer (Lydolph et al., 1985).

Figure 7 shows an example of the wind velocity of the meridional-height section from cruise ANT-XVII. Pronounced maxima in the tropopause regions are clearly visible. They belong to the four westerly jet streams. In the Northern Hemisphere the polar jet is clearly separated from the subtropical jet while in the Southern Hemisphere both jets coincide to be very close to each other. 


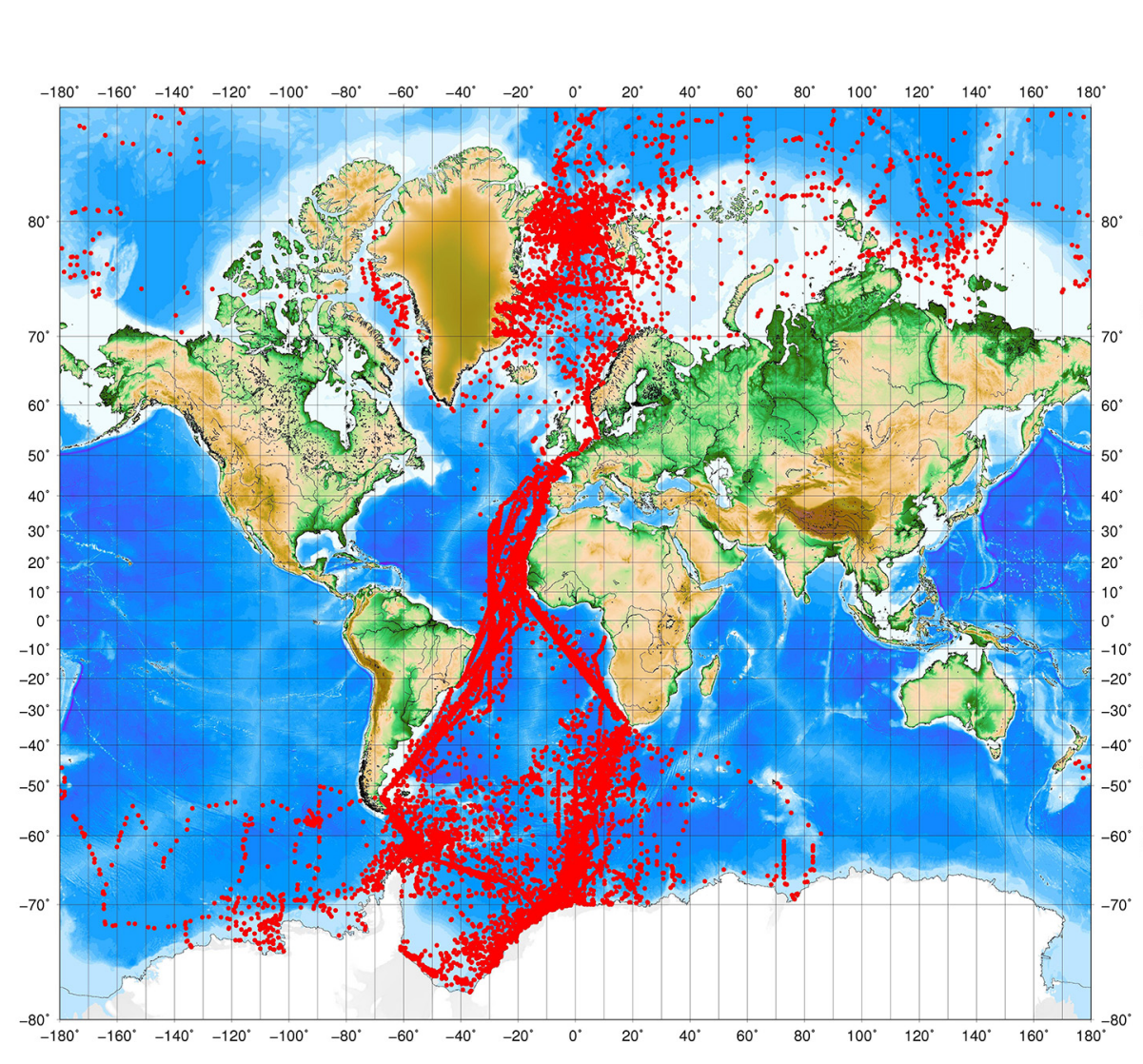

Ship: R.V. Polarstern

Date: $29.12 .1982-25.11 .2012$
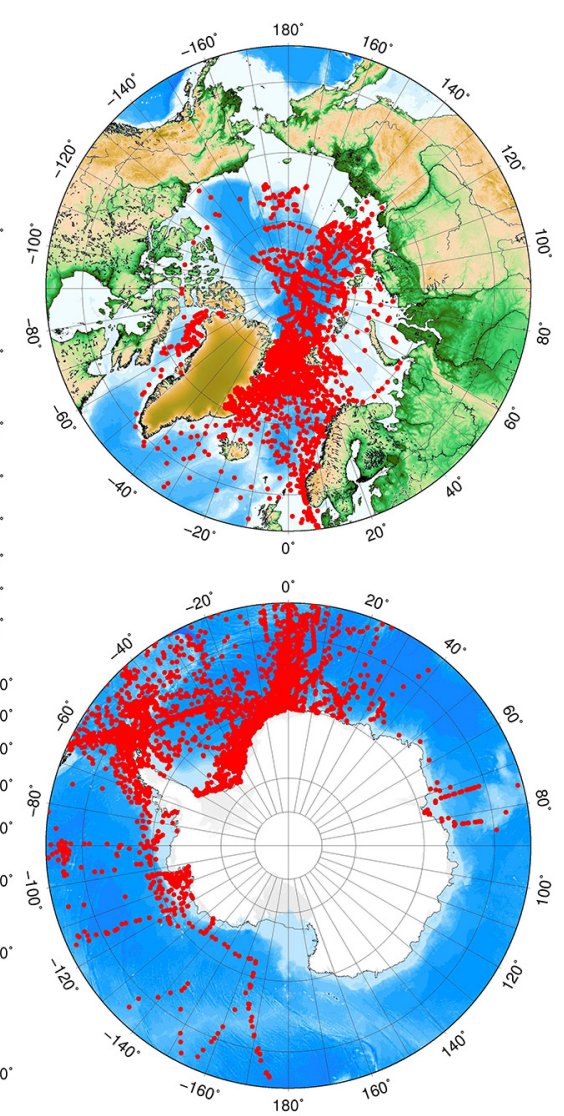

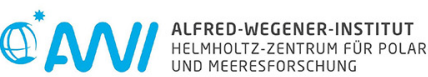

Figure 2. Map showing the locations of 30 years of radiosonde launches performed from POLARSTERN. From Antarctic cruise ANT-I/1 on 29 December 1982 until the end of ANT-XXIX/1, on 25 November 2012.

Examples of practical applications of POLARSTERN radiosonde data can be found in various scientific articles, for example in Immler and Schrems (2002), in John et al. (2006) or in Yamazaki et al. (2015) to mention just a few.

\subsection{Data quality}

The radiosonde data presented here have been measured by three different VAISALA sensors (RS80, RS90 and RS92). To optimize the data quality, the changes of the radiosonde types have to be taken into account. The data archived in PANGAEA represent the original values which were provided by the VAISALA reception and evaluation system (i.e. after the intrinsic processing of the reception system). Except for the altitudinal information, which was calculated using the hydrostatic approximation, and a general check of the overall data quality (see below), the data were not corrected for known systematic errors or biases. In the following, we provide an overview of the general checks applied, and we then elucidate the known biases and the respective correction proposals for interested users.
General checks applied:

- Validation of position and date/time via cross-check with other POLARSTERN data sets of the respective cruise station

- Removal of outliers exceeding the physically possible limits

- Removal of data points where thermal statification was unstable

- Removal of data points where pressure was not decreasing strictly monotonically

- Removal of data points where relative humidity exceeded $100 \%$ with respect to ice

The general checks led to the exclusion of only very few data points, as the intrinsic data reception systems of the senors described above already removed most of these inconsistencies. 

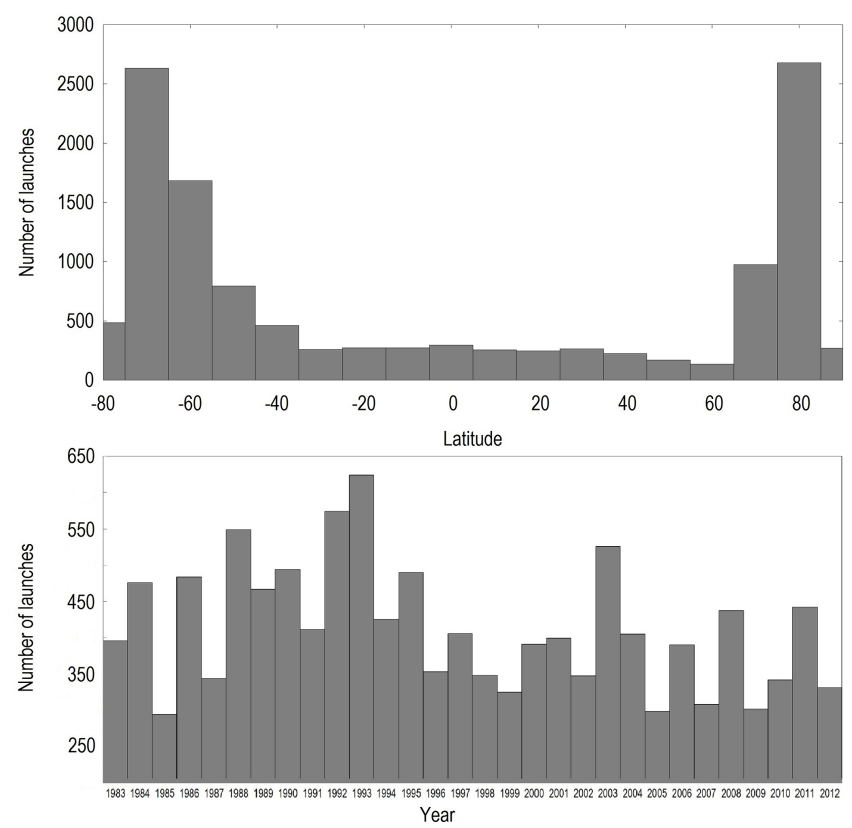

Figure 3. The distribution of POLARSTERN radiosonde launches according to latitude (upper part) and year (lower part).

Known biases and correction proposals:

- RS80

- The A-type HUMICAP humidity sensor is known to have a considerable dry bias mainly at low temperatures (Miloshevich et al., 2001). Correction methods have been proposed by Wang et al. (2002).

- Also a time lag has been identified occurring due to the long response time of the humidity sensor at low temperatures. The proposed correction is to apply an algorithm published in Miloshevich et al. (2004).

- In ice-supersaturated conditions ice-coating of the humidity sensor sometimes causes the measurements to stay near ice-saturation over large parts of the troposphere, not reflecting the conditions of the ambient air.

- RS90:

The RS90 is equipped with two H-type HUMICAP humidity sensors that are alternately heated to remove condensed water or ice, thus avoiding the effect of sensor icing.

- A small time lag is still present, even though the $\mathrm{H}$ polymer has a faster sensor response time. Again, the according time constant in the correction algorithm of Miloshevich et al. (2004) can be used to correct this.

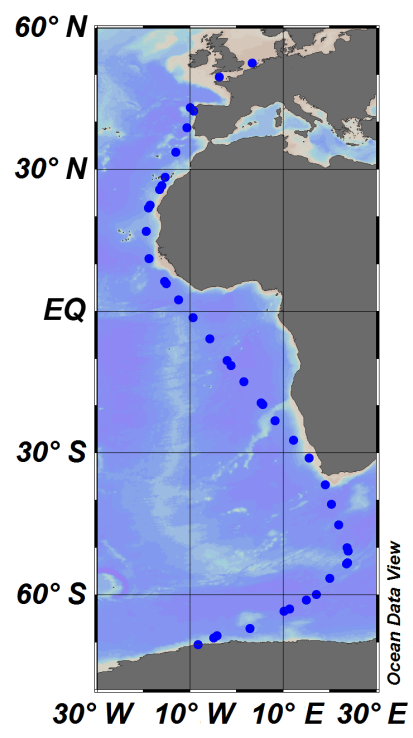

Figure 4. Locations of radiosonde launches performed from $P O$ LARSTERN during cruise ANT-XVII (14 December 1999 to 20 January 2000).

Humidity data from all three VAISALA radiosondes suffer from the so-called daytime solar radiation dry bias (SRDB). Not being shielded against solar radiation, the sensors can be heated by incoming short-wave radiation during daytime launches (see, e.g. Wang et al., 2003, 2013; Vömel et al., 2007). However, the RS92 operated together with the VAISALA DigiCORA Sounding System MW31 were ranked to be the world's top radiosonde at the 8th WMO Intercomparison of Radiosonde Systems in 2010 and GRUAN compatible (Nash et al., 2011).

Another source of biases can be ship-specific influences such as heating and/or cooling biases discussed in Ciesielski et al. (2004). As already stated in Sect. 2, all soundings on board of POLARSTERN were started from the helideck at a height of $10 \mathrm{~m}$ a.s.l., resulting in data sets beginning at an altitude of $10 \mathrm{~m}$ a.s.l. The values for this first data point of radiosonde launches normally are taken from ground measurements. Due to the fact that no unbiased ground measurements can be taken on a ship, the (largely unbiased) values of the ship's Luv-sensors ( $29 \mathrm{~m}$ a.s.l. for temperature and humidity, $39 \mathrm{~m}$ a.s.l. for wind) were used. The air pressure value for this first data point was calculated from the ship's meteorological observatory (16 $\mathrm{m}$ a.s.l.). The pressure sensor has an external inlet which ends in a labyrinth in the ship's mast to reduce ship-specific influences. Beginning with the second data point (altitude level), the data originate from the radiosonde itself. In the rare case that the quality check revealed ongoing disturbances for the second data point (e.g. by the ship's plume), the respective data were deleted from the records. For the third altitude level onwards, no shipbased biases were expected anymore. 


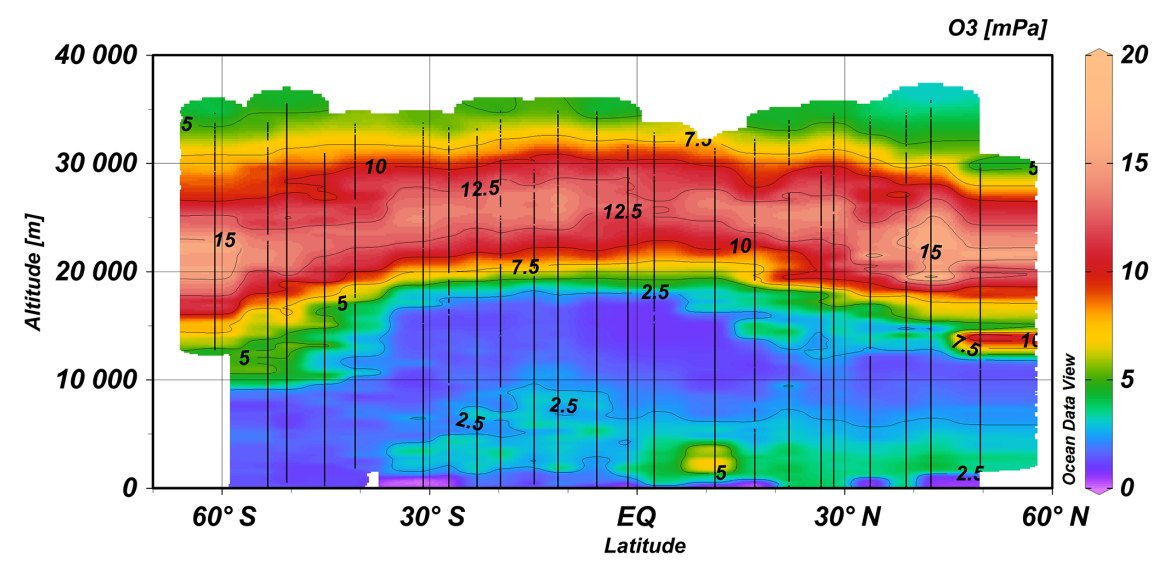

Figure 5. Meridional-height section of ozone $\left(\mathrm{O}_{3}\right.$ in $\left.\mathrm{mPa}\right)$ from POLARSTERN cruise ANT-XVII (14 December 1999 to $\left.20 \mathrm{January} 2000\right)$. The lines represent the actual launches, the data were then interpolated to obtain this figure.

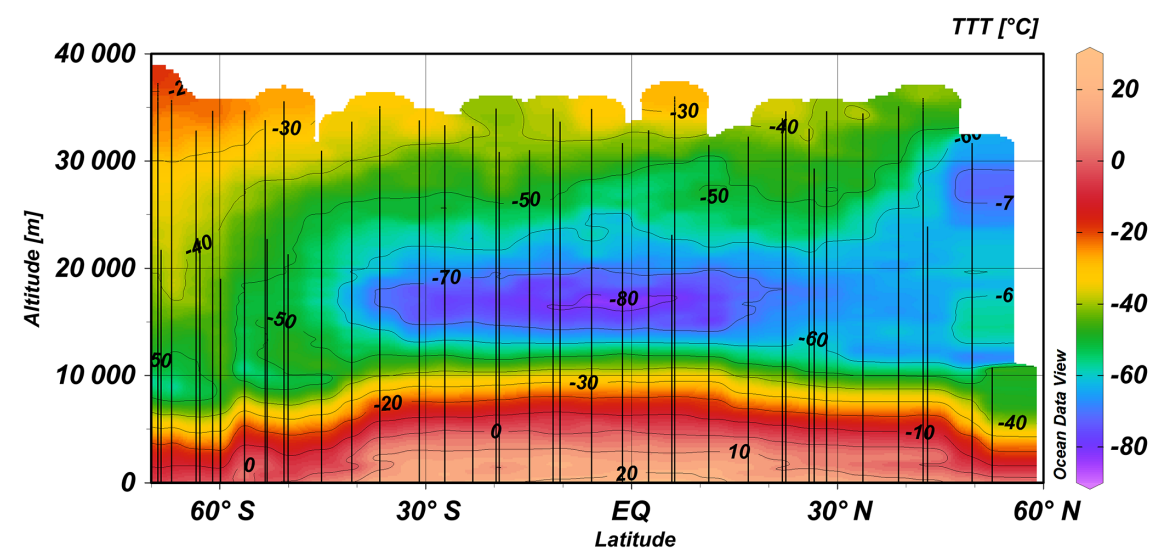

Figure 6. Meridional-height section of air temperature (TTT in ${ }^{\circ} \mathrm{C}$ ) from POLARSTERN cruise ANT-XVII (14 December 1999 to 20 January 2000). The lines represent the actual launches, the data were then interpolated to obtain this figure.

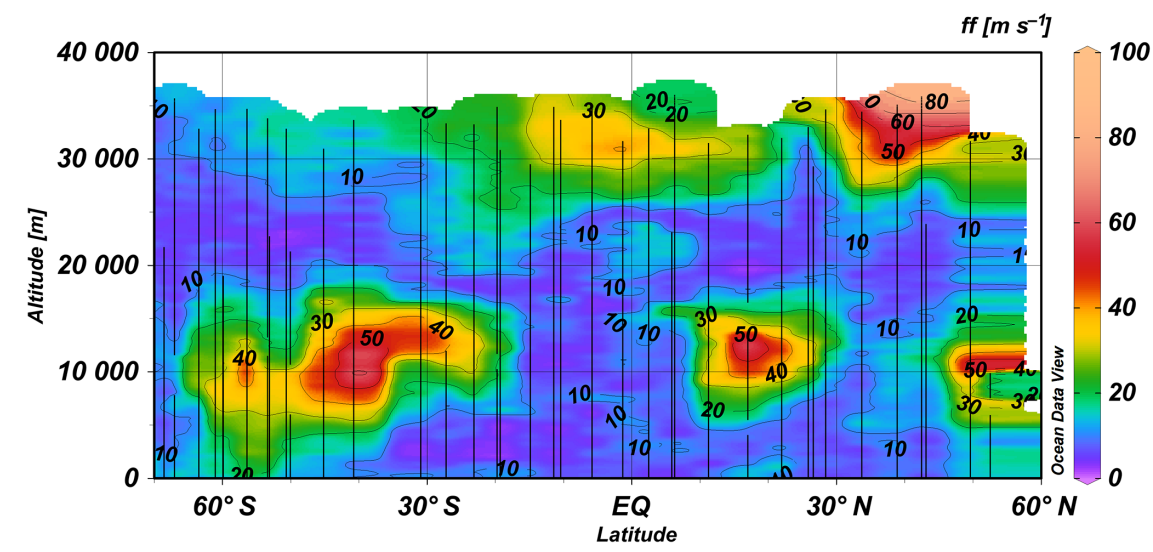

Figure 7. Meridional-height section of wind velocity ( $\mathrm{ff}$ in $\mathrm{m} \mathrm{s}^{-1}$ ) from POLARSTERN cruise ANT-XVII (14 December 1999 to 20 January 2000). The lines represent the actual launches, the data were then interpolated to obtain this figure. 


\subsection{Related upper air data in PANGAEA}

Radiosonde measurements on POLARSTERN are ongoing. Since 25 November 2012, which is the date of the last radiosonde launch discussed above, data of an additional 1186 POLARSTERN radiosonde launches have been archived in PANGAEA (status 15 May 2016). Apart from these, PANGAEA contains 12057 soundings performed at the Antarctic research station Neumayer and 9911 from the Arctic station Ny Ålesund (status 15 May 2016). Both AWI stations are part of the Baseline Surface Radiation Network (BSRN) which uses PANGAEA as its central archive (König-Langlo et al., 2013). For an overview of BSRN radiosonde data (monthly files) see http://www.pangaea.de/PHP/BSRN_Status.php?q= LR1100.

\section{Conclusions}

Even though more sophisticated techniques (meteorological satellites, aircraft observation, remote sensing systems, etc.) have become increasingly important in weather forecasts, the high vertical resolution and quality of radiosonde data remains crucial for weather forecast quality, for detecting changes in climate, and for the validation of modelling and satellite products (Dow, 2004). The Alfred Wegener Institute is committed to providing high-quality and open-access research data to the scientific community and the interested public, and will thus continue with upper air soundings (and other under-way measurements) on board of POLARSTERN until its decommissioning. The new research vessel $P O$ LARSTERN II, which according to the current schedule will be handed over to the scientific community in 2019, will most likely continue the work of over 30 years of dedicated $P O$ LARSTERN meteorology.

Acknowledgements. We are very grateful for the time and effort the two reviewers put into improving our manuscript, your help is highly appreciated. We would also like to thank Wolfgang Cohrs for the technical assistance and the creation of Fig. 2. Special thanks to all DWD weather technicians on board of POLARSTERN responsible for launching the sondes: Hans Ohlendorf, Dieter Bassek, Herbert Köhler, Wolf-Thilo Ochsenhirt, Juliane Schostak, Hartmut Sonnabend, Roland Menzel, Hans-Peter Lambert, Klaus Buldt, Edmund Knuth, Thorsten Truscheit, and Juliane Hempelt.

Edited by: D. Carlson

\section{References}

Ciesielski, P. E., Yu, H., Johnson, R. H., Yoneyama, K., Katsumata, M., Long, C. N., Wang, Junhong., Loehrer, Scot, M., Young, Kathryn., Williams, Steven.F., Brown, W., Braun, J., and Van Hove, T.: Quality-controlled upper-air sounding dataset for DYNAMO/CINDY/AMIE: Development and corrections, J. Atmos.
Ocean. Tech., 31, 741-764, doi:10.1175/JTECH-D-13-00165.1, 2014.

Dow, G.: Developments in Observational Requirements for Global Numerical Weather Prediction, University of Reading, Department of Meteorology, Reading, 2004.

DuBois, J. L., Multhauf, R. P., and Ziegler, C. A.: The invention and development of the radiosonde: with a catalog of upper-atmospheric telemetering probes in the National Museum of American History, Smithsonian Institution, Smithsonian studies in history and technology, 53, $88 \mathrm{pp}$. doi:10.5479/si.00810258.53.1, 2002.

Fütterer, D. and Fahrbach, E.: POLARSTERN - 25 Jahre Forschung in Arktis und Antarktis, Bielefeld, Delius Klasing, 293 pp., ISBN: 978-3-7688-2433-0, 2007.

Immler, F. and Schrems, O.: Determination of tropical cirrus properties by simultaneous LIDAR and radiosonde measurements, Geophys. Res. Lett., 29, 2090, doi:10.1029/2002GL015076, 2002.

John, V. O., Buehler, S. A., von Engeln, A., Eriksson, P., Kuhn, T., Brocard, E., and Koenig-langlo, G.: Understanding the variability of clear-sky outgoing long-wave radiation based on shipbased temperature and water vapour measurements, Q. J. Roy. Meteor. Soc., 132, 2675-2691, doi:10.1256/qj.05.70, 2006.

König-Langlo, G.: 30 years of upper air soundings on board of R/V POLARSTERN (1982-12-29 to 2012-11-25), Alfred Wegener Institute, Helmholtz Center for Polar and Marine Research, Bremerhaven, doi:10.1594/PANGAEA.810000, 2015.

König-Langlo, G., Loose, B., and Bräuer, B.: 25 Years of POLARSTERN Meteorology, WDC-MARE Reports, 4, CD+booklet, 137 pp., doi:10.2312/wdc-mare.2006.4, 2006.

König-Langlo, G., Sieger, R., Schmithüsen, H., Bücker, A., Richter, F., and Dutton, E. G.: The Baseline Surface Radiation Network and its World Radiation Monitoring Centre at the Alfred Wegener Institute, WCRP Report 24/2013, GCOS - 174, available at: www.wmo.int/pages/prog/gcos/Publications/gcos- 174 . pdf, 2013.

Lydolph, P., Temple, D., and Temple, D.: The Climate of the Earth, Rowman \& Littlefield Publishers, Inc., Lanham, 408 pp., 1985.

Miloshevich, L. M., Vömel, H., Paukkunen, A., Heymsfield, A. J., and Oltmans, S. J.: Characterization and correction of relative humidity measurements from Vaisala RS80-A radiosondes at cold temperatures, J. Atmos. Ocean. Tech., 18, 135-155, 2001.

Miloshevich, M., Paukkunen, A., Vömel, H., and Oltmans, S.: Development and Validation of a Time-Lag Correction for Vaisala Radiosonde Humidity Measurements, J. Atmos. Ocean. Tech., 21, 1305-1327, doi:10.1175/15200426(2004)021<1305:DAVOAT>2.0.CO,2, 2004.

Nash, J., Oakley, T., Vömel, H., and Li, Wei.: WMO Intercomparison of high quality radiosonde systems, Yangjiang, China, 12 July-3 August 2010, World Meteorological Organization, Instruments and Observing Methods, Report No. 107, WMO/TDNo. 1580, 2011.

Schlitzer, R.: Ocean Data View, available at: http://odv.awi.de (last access:4 January 2016), 2015.

Vömel, H., Selkirk, H., Miloshevich, L., Valverde-Canossa,J., Valdés, J., Kyrö, E., Kivi, R., Stolz, W., Peng, G., and Diaz, J. A.: Radiation Dry Bias of the Vaisala RS92 Humidity Sensor, J. Atmos. Ocean. Tech., 24, 953-963, doi:10.1175/JTECH2019.1, 2007. 
Wang, J., Cole, H. L., Carlson, D. J., Miller, E. R., and Beierle, K.: Corrections of humidity measurement errors from the Vaisala RS80 radiosonde - application to TOGA COARE data, J. Atmos. Ocean. Tech., 19, 981-1002, doi:10.1175/15200426(2002)019<0981:COHMEF>2.0.CO,2, 2002.

Wang, J., Carlson, D. J., Parsons, D. B., Hock, T. F., Lauritsen, D., Cole, H. L., Beierle, K., and Chamberlain, N.: Performance of operational radiosonde humidity sensors in direct comparison with a chilled mirror dew-point hygrometer and its climate implications, Geophys. Res. Lett., 30, 1860, doi:10.1029/2003GL016985, 2003.
Wang, J., Zhang, L., Dai, A., Immler, F., Sommer, M., and Vömel, H.: Radiation dry bias correction of Vaisala RS92 Humidity data and its impacts on historical radiosonde data, J. Atmos. Ocean. Tech., 30, 197-214, doi:10.1175/JTECH-D-12-00113.1, 2013.

Yamazaki, A., Inoue, J., Dethloff, K., Maturilli, M., and KönigLanglo, G.: Impact of radiosonde observations on forecasting summertime Arctic cyclone formation, J. Geophys. Res. Atmos., 120, 3249-3273, doi:10.1002/2014JD022925, 2015. 